\title{
Epidermodysplasia Verruciformis in a young man with HIV since birth - Case report
}

Epidermodisplasia Verruciforme em um jovem com HIV desde o nascimento - Relato de caso

\author{
Sheila Itamara Ferreira do Couto Meireles ${ }^{1}$ \\ Cristiano Luiz Horta de Lima Júnior ${ }^{3}$
}

\author{
Sônia Maria Fonseca de Andrade ${ }^{2}$ \\ Mario Cezar Pires ${ }^{4}$
}

Abstract: Epidermodysplasia Verruciformis is a genodermatosis characterized by susceptibility to infection by specific HPV types (HPV 3/10 and beta-HPVs). It is considered to be the first model in human carcinogenesis induced by HPV. In this report we present a rare case of Epidermodysplasia Verruciformis associated with vertical transmission of HIV. Although most patients with HIV present infections by HPV virus, the frequency of Epidermodysplasia Verruciformis is no greater in patients with HIV because in EV there is a deficiency of specific cellular immunity to infection by some types of HPV, called HPV-related Epidermodysplasia Verruciformis. Keywords: DNA probes, HPV; Epidermodysplasia verruciformis; HIV; HIV infections; Immunity, cellular

Resumo: A Epidermodisplasia Verruciforme é uma genodermatose que se caracteriza pela susceptibilidade à infecção por tipos específicos de HPV (HPVs 3 e 10 e os beta-HPVs) e é considerada o primeiro modelo no homem de carcinogênese induzida pelo HPV. Neste artigo apresenta-se um caso raro de Epidermodisplasia Verruciforme em um paciente com HIV desde o nascimento. Apesar dos doentes com HIV apresentarem mais infecções pelos vírus HPVs, existem poucos relatos na literatura de Epidermodisplasia Verruciforme no doente com HIV. Isso se explica, pois a Epidermodisplasia Verruciforme é consequência de uma deficiência celular específica à infecção por alguns tipos distintos de HPVs, ditos HPVs relacionados a Epidermodisplasia Verruciforme.

Palavras-chave: Epidermodisplasia verruciforme; HIV; Imunidade celular; Infecções por HIV; Sondas de DNA de HPV

\section{INTRODUCTION}

Epidermodysplasia Verruciformis (EV) is a rare affection of recessive autosomal transmission as described by Lutz and Lewandowski in 1922 , although there are reports of a possible recessive heritage connected to the $\mathrm{X} \cdot{ }^{1,2,3} \mathrm{EV}$ can be both familial and sporadic. Androphy et al consider the sporadic form more common. ${ }^{4,5}$

EV is characterized by a susceptibility to chronic infections by different types of Human Papiloma Virus (HPV). ${ }^{3}$

The specific HPVs involved in the EV pathogenesis are 3 and/or 10 types (associated to flat verruca), and the beta-HPVs 5, 8, 9, 12, 14, 15, 17, 19-25, 36-38, 47 and 50 types.
The clinical picture begins in childhood and adolescence (5-11 years). It is expressed by flat verruca-type lesions, maculae and isolated or confluent papule, erythematous and/or hypochromic, and can present desquamation. The lesions generally begin on the face and in the cervical region, with later generalization, but sparing the scalp and mucosa. Itching and ardor appear occasionally, normally associated with sun exposure. . $^{1,23}$

The clinical lesions can resemble a flat verruca, versicolor pityriasis, psoriasis and seborrheic keratoses. ${ }^{1,2,3}$

EV diagnosis must be suspected when persistent verrucas are present in large body areas and are thus difficult to treat. ${ }^{6}$

EV patients possess specific cellular immunity

Received on 01.12.2012.

Approved by the Advisory Board and accepted for publication on 18.02.2013.

* Work performed at the Padre Bento de Guarulhos Hospital Complex- Guarulhos (SP), Brazil.

Conflict of interest: None

Financial funding: None

Medical doctor - Resident in the Dermatology Service of the Padre Bento de Guarulhos Hospital Complex- Guarulhos (SP), Brazil.

Dermatologist - Assistant physician in the Dermatology Service of the Padre Bento de Guarulhos Hospital Complex- Guarulhos (SP), Brazil.

Master in skin oncology from the Fundação Antônio Prudente - Hospital AC Camargo - Assistant physician in the Dermatology Service of the Padre Bento de Guarulhos Hospital Complex- Guarulhos (SP), Brazil.

Doctorate in dermatology, State Public Employees Hospital, and Director of the Research Unit at the Padre Bento de Guarulhos Hospital ComplexGuarulhos (SP), Brazil. 
against certain kinds of HPV. Consequently, flat wart lesions are distributed generally, and on account of the oncogenic action of the virus, actinic keratosis and carcinomas can develop, mainly in photo-exposed areas. Lesions can become malignant in approximately $30 \%$ of cases, more commonly in the third and fourth decades of life, and spinocellular carcinoma, the most frequent type, can be aggressive and even present metastasis. ${ }^{2}$

Histologically, the lesions present stereotypical keratinocytes enlarged on the upper epidermis with a grey-blue cytoplasm and pyknotic nucleus. ${ }^{1,23,6}$

The present case report refers to a patient with EV and vertical infection by HIV.

\section{CASE REPORT}

22-year-old male reporting non-pruriginous lesions which appeared in the pre-adolescent period, initially on the neck, with later dissemination. $\mathrm{He}$ denied relatives with a similar condition and consanguinity between his parents. HIV was present since birth, and the patient was under non-regular treatment with antiretroviral drugs.

Dermatological examination showed isolated flat and some confluent, erythematous papulae, discreetly desquamative on the neck, trunk, and limbs. (Figures 1-3)

Laboratory examinations showed positive antiHIV, CD4: 84; Viral Load: 4.188.

The histopathological examination revealed wide grayish-blue keratinocytes with pyknotic nucleus on the upper third of the epiderm. These findings were compatible with EV. (Figures 4 and 5)

The in situ hybridization was negative to the 6-1116-18-31-33-35-39-45-51-52-56-58-59-68 HPVs. These were not present in the $\mathrm{EV}$, thus allowing an accurate diagnosis to be made.

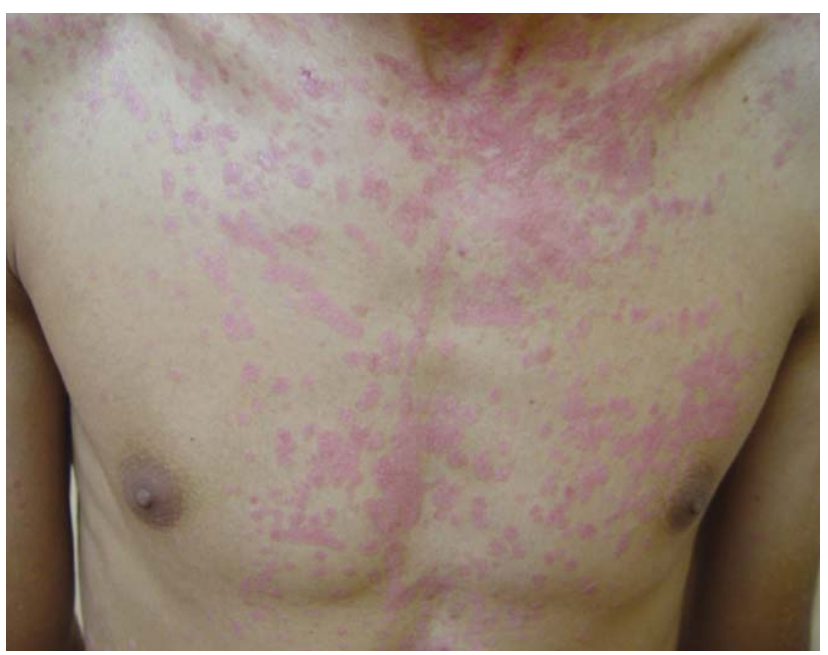

FigurE 1: Isolated and confluent erythematous papulae forming verruca-type plaques on the upper chest

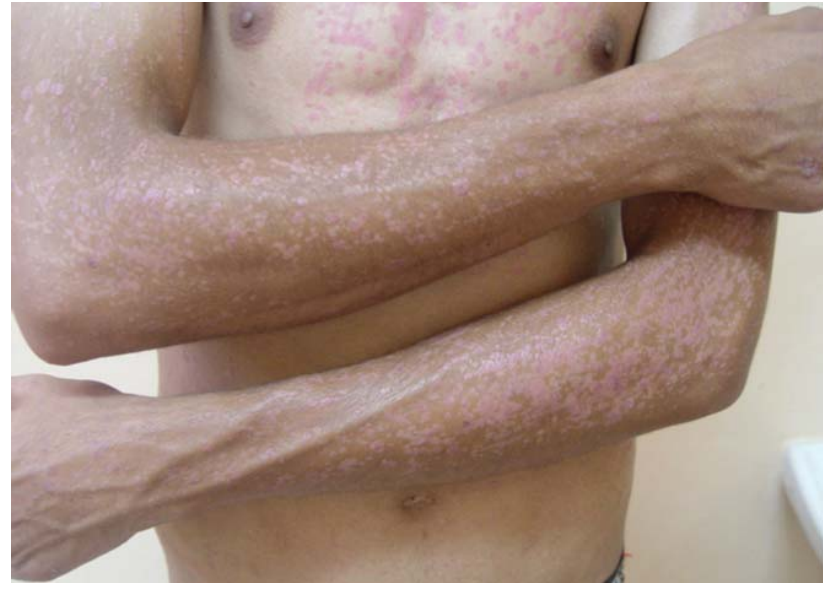

FIGURE 2: Erythematous and hypochromic verrucous papulae on the backs of the forearms

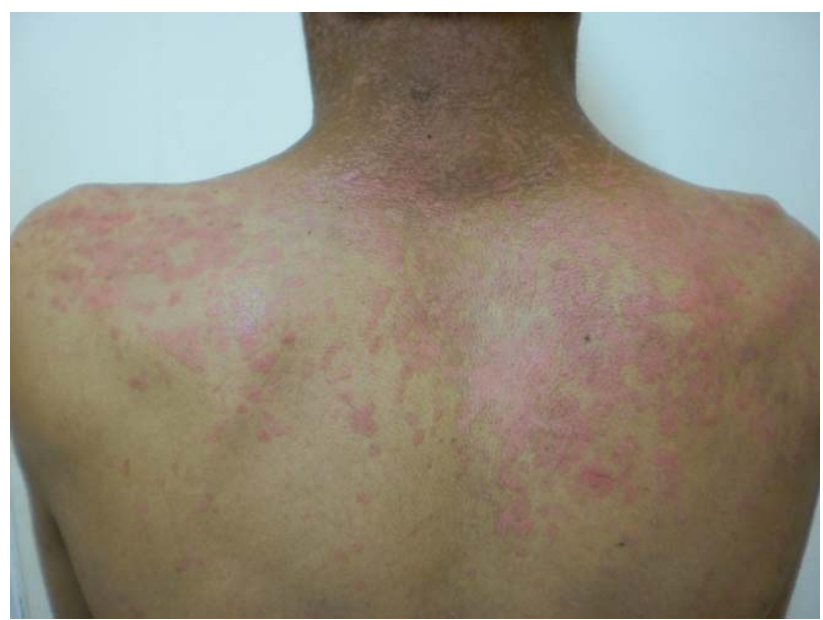

FIGURE 3: Erythematous and hypochromic desquamative plaques on the back

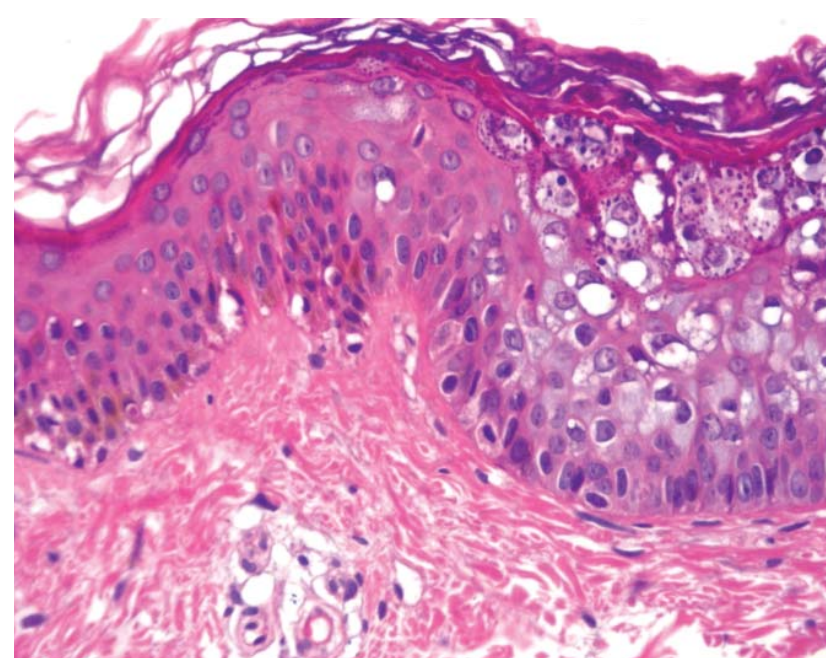

FIGURE 4: Transition from the normal epidermis and the compromised area 
Treatment with oral acitretine was proposed but the patient missed follow-up at our dermatology clinic.

\section{DISCUSSION}

$\mathrm{EV}$ is a genodermatosis characterized by susceptibility to the infection by specific types of HPVs ( 3 and 10 HPVs and beta-HPVs). It is considered to be the first model of carcinogenesis in men induced by HPV.

The clinical picture of EV may present only flat verruca associated to non-oncogenic 3 and/or $10 \mathrm{HPVs}$, called the "benign form", or expressed in a polymorphic way tending to malignancy associated with multiple HPVs, the major ones being: 5, 8, 14 and 47, called the "malignant form". The initial presence of flat verrucas followed by the onset of a polymorphism characteristic of the malignant form defines the "mixed form".

This patient was considered to carry EV in its benign form, since dissemination consisted only of similar flat wart lesions. Moreover, the hystopathological examination showed the cytopatic effect of the virus only on the upper part of the epidermis, typical of the benign form, while the malignant form involves the entire epidermis (Figure 5).

The condition is not specifically related to gender or race. Reports suggest that around 10\% of EV carriers are the product of a consanguineous marriage. Our patient's parents did not however report consanguinity. We considered the case as sporadic given that the patient denied having relatives with a similar disease.

Infection by the HPV virus in HIV carriers is common, but fewer than 20 cases of EV have been reported in patients infected with HIV. ${ }^{6}$ A possible explanation might be that EV poses immunological changes of specific cellular immunity against different types of HPVs: beta-HPVs and the 3 and 10 HPVs. Such immunological deficiency would appear to be local and

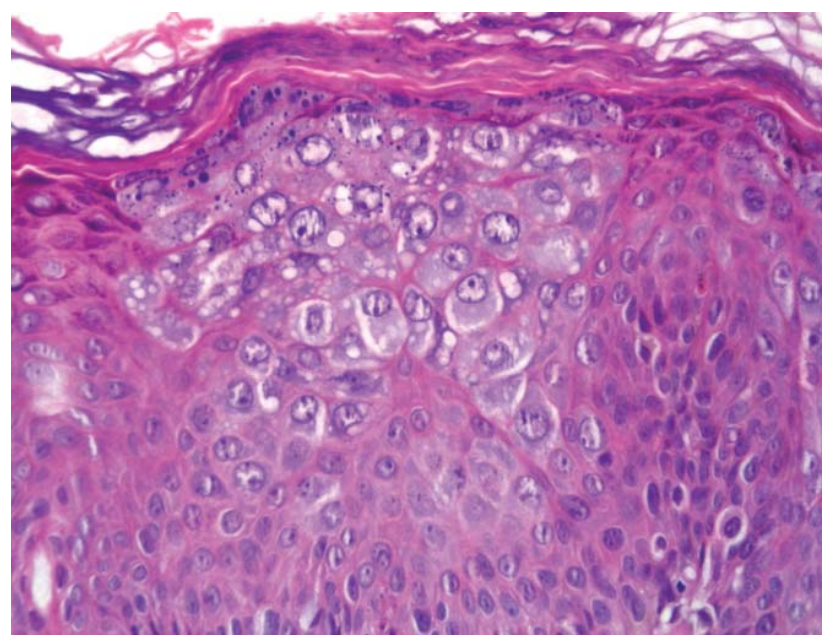

FIGURE 5: Stereotypical grayish-blue cytoplasm and keratinocytes with pyknotic nucleus on the upper epiderm

exclusive, determining the inappropriate presentation of specific antigens to HPV defense cells. ${ }^{1}$

There are even fewer such cases described in the EV literature on HIV vertically infected patients, as in this particular case. ${ }^{7}$

No definitive treatment exists for EV, but photoprotection is recommended from childhood onwards.

Treatment of EV with oral retinoids has been described as producing a number of benefical effects including their antiviral and antineoplasmatic actions. The use of systemic or intra-injury Alpha-2a Interferon alfa-2a has also been described, with immunomodulator, antiviral and antiproliferous actions.

Silva et al have reported a case treated with oral $0.75 \mathrm{mg} / \mathrm{kg} /$ day Acitretine and Alpha-2a Interferon 3.000.000 UI via SC, 3 times a week, with almost complete regression of the lesions and few collateral effects. $\left.{ }^{2}\right]$

\section{REFERENCES}

1. Oliveira WRP, Neto CF, Tyring SK. Clinical aspects of epidermodysplasia verruciformis. An Bras Dermatol. 2002;77:545-56.

2. Silva CS, Ramos R0, Pires MC, Sittart JAS. Epidermodysplasia verruciformis: combined treatment with acitretin and interferon alpha-2a. An Bras Dermatol. 2006; 81:595-7.

3. Sá NB, Guerini MB, Barbato MT, Di Giunta G, Nunes DH. Epidermodysplasia verruciformis: clinical presentation with varied forms of lesions. An Bras Dermatol. 2011;86:S57-60.

4. Androphy EJ, Dvoretzky I, Lowy DR. X-linked inheritance of epidermodisplasia verruciformis. Arch Dermatol. 1985;121:864-8.

5. Berk DR, Bruckner AL, Lu D. Epidermodysplasia verruciform-like lesions in an HIV patient. Dermatol Online J. 2009;15:1.

6. Fitzpatrick TB. Tratado de dermatologia, 7. ed. Rio de Janeiro: Revinter; 2011. Capítulo 196, Infecção pelo papilomavírus; p.1914-23.

7. Lowe SM, Katsidzira L, Meys R, Sterling JC, de Koning M, Quint W, et al. Acquired epidermodysplasia verruciformis due to multiple and unusual HPV infection among vertically-infected, HIV-positive adolescents in Zimbabwe. Clin Infect Dis. 2012;54:e119-23. An Bras Dermatol. 2013;88(6 Suppl 1):190-2.

\author{
MAILING ADDRESS: \\ Sheila Itamara Ferreira do Couto Meireles \\ Av Emílo Ribas, 1819- Guarulhos \\ 07050-001 - São Paulo - SP \\ Brazil \\ E-mail: sheilaifc@bol.com.br
}

How to cite this article: Meireles SIFC, Andrade SMF, Lima CLH Jr, Pires MC. Report of a case of Epidermodysplasia Verruciformis in young man with HIV since birth. An Bras Dermatol. 2013;88(6 Suppl 1):S190-2. 